Reviu Akuntansi dan Bisnis Indonesia, Vol. 5 No. 2, Hlm 112-121, Desember 2021

Website: http://journal.umy.ac.id/index.php/rab

\title{
Koneksi Politik dan Kualitas Audit: Peran Moderasi dari Manajemen Laba
}

\author{
Andreas Vernando; Rintan Nuzul Ainy \\ Program Studi Akuntansi Universitas Ahmad Dahlan
}

\section{N F O A R T I K E L}

Kata Kunci:

Koneksi Politik; Kualitas

Audit; Manajemen Laba;

Moderasi

Jenis Artikel:

Penelitian Empiris

\section{Korespondensi:}

andreas.vernando@act.uad.ac.id

Proses Artikel:

Diterima 5 Juni 2021

Review 5 Agustus 2021

Revisi 21 Oktobe 2021

Revisi 18 November 2021

Diterbitkan 1 Desember 2021

Sitasi:

Vernando, A., \& Ainy, R.N. (2021). Koneksi Politik dan Kualitas Audit: Peran

Moderasi dari Manajemen

Laba. Reviu Akuntansi dan

Bisnis Indonesia, 5(2), 112-

121.

Link Artikel:

10.18196/rabin.v5i2.11903

\section{A B S T RA K}

\section{Latar Belakang:}

Hasil penelitian sebelumnya terkait hubungan antara koneksi politik dan kualitas audit masih inkonklusif. Penelitian sebelumnya telah menyediakan bukti empiris bahwa perusahaan yang terkoneksi politik berhubungan negatif terhadap kualitas audit (Habib dkk., 2017a; Cheng dkk., 2015), tetapi studi lainnya menemukan bahwa perusahaan yang terkoneksi politik berhubungan positif terhadap kualitas audit (Armadiyanti \& Iswati, 2019; Guedhami dkk., 2013; Harymawan \& Nowland, 2016)

\section{Tujuan:}

Penelitian ini bertujuan untuk menguji manajemen laba dalam memoderasi hubungan antara koneksi politik dan kualitas audit.

\section{Metode Penelitian:}

Penelitian ini menggunakan sampel sejumlah 895 observasi di seluruh perusahaan nonfinansial yang terdaftar di Bursa Efek Indonesia dan menggunakan regresi logistik.

\section{Hasil Penelitian:}

Penelitian ini menemukan bahwa terdapat hubungan positif antara koneksi politik dan kualitas audit. Hal ini mengindikasikan bahwa perusahaan yang terkoneksi politik memberikan sinyal positif kepada partisipan pasar bahwa perusahaan telah dikelola dengan lebih akuntabel dan transparan. Selain itu, hasil penelitian ini juga menemukan bahwa manajemen laba memoderasi hubungan koneksi politik dan kualitas audit. Ketika melakukan manajemen laba, perusahaan yang terkoneksi politik memilih auditor tidak berkualitas dalam rangka untuk menutupi praktik manajemen labanya tersebut.

\section{Keterbatasan Penelitian:}

Karena kesulitan untuk mengumpulkan data terkait variabel koneksi politik di laporan tahunan, penelitian ini hanya mampu melakukan observasi perusahaan nonfinansial selama 2017-2018.

\section{Keaslian/Novetly Penelitian:}

Penelitian ini memperluas penelitian Habib dkk. (2017a) dengan menggunakan variabel manajemen laba sebagai faktor pemoderasi dan menggunakan perspektif yang berbeda dari penelitian Armadiyanti dan Iswati (2019) terkait koneksi politik diduga berhubungan positif terhadap kualitas audit.

(C) 2021 RAB. Published by Universitas Muhammadiyah Yogyakarta 


\section{PENDAHULUAN}

Penelitian sebelumnya telah menyediakan bukti empiris bahwa perusahaan yang terkoneksi politik tidak memilih auditor yang berkualitas untuk menutupi ekspropriasi sumber daya (Habib dkk., 2017a) dan manajemen laba (Cheng dkk., 2015). Akan tetapi, studi lain menemukan bahwa perusahaan yang terkoneksi politik lebih memilih auditor yang berkualitas untuk menyakinkan partisipan pasar bahwa perusahaan tersebut telah dikelola dengan baik (Armadiyanti \& Iswati, 2019; Guedhami dkk., 2013; Harymawan \& Nowland, 2016).

Dengan melihat hasil penelitian yang inkonklusif, Habib dkk. (2017a) meneliti pengaruh transaksi kepada pihak yang berelasi ' dalam memoderasi hubungan koneksi politik dan pemilihan auditor. Hasilnya ditemukan bahwa transaksi hubungan istimewa (related party transaction) menjadi faktor yang memotivasi perusahaan terkoneksi politik untuk tidak memilih auditor yang berkualitas untuk menutupi pengalihan sumber daya (tunneling).

Armadiyanti dan Iswati (2019) telah menginvestigasi asosiasi antara koneksi politik dan kualitas auditor dan mereka berargumen bahwa koneksi politik memilih auditor yang tidak berkualitas. Berbeda dengan penelitian sebelumnya, penelitian ini menduga perusahaan yang terkoneksi politik cenderung memilih auditor yang berkualitas. Kondisi (setting) ini menfasilitasi ruang untuk melakukan manajemen laba karena perusahaan yang terkoneksi politik mendapatkan berbagai benefit dari hubungannya dengan pemerintah sehingga manajer di perusahaan tersebut cenderung menutupi keuntungan ini dengan melakukan manajemen laba (Chaney dkk., 2011). Sebagai konsekuensi logisnya, perusahaan yang terkoneksi politik cenderung memilih auditor yang berkualitas jika manajer tidak melakukan tindakan yang merugikan investor (self-serving behavior) dalam rangka untuk menyakinkan partisipan pasar bahwa perusahaan tersebut tidak berisiko. Dengan demikian, tujuan dari penelitian ini adalah untuk menginvestigasi pengaruh moderasi manajemen laba dalam hubungan koneksi politik dengan kualitas auditor.

Keputusan ekonomi yang rasional, pada umumnya, dipengaruhi oleh pertimbangan antara manfaat dan biaya. Pertimbangan ini juga berlaku ketika menentukan apakah perusahaan yang terkoneksi memilih auditor yang berkualitas atau tidak (Fan \& Wong, 2005; Liu dkk., 2016). Jika perusahaan memilih auditor yang berkualitas, manfaatnya adalah masalah agensi dan asimetri informasi menurun (Guedhami dkk., 2009, 2014; Guedhami \& Pittman, 2006; Knechel dkk., 2008) yang pada akhirnya menurunkan biaya modal (Francis dkk., 2004). Di samping itu, jika memilih auditor berkualitas, perusahaan akan menanggung biaya yakni fleksibilitas manajemen terhambat untuk melakukan ekspropriasi sumber daya, seperti melakukan tunneling melalui transaksi dengan perusahaan yang berafiliasi (Chaney dkk., 2011; Habib dkk., 2017a; He dkk., 2014; Shleifer \& Vishny, 1997) dan memberikan kompensasi yang berlebihan (Anderson \& Reeb, 2003).

Penelitian ini berkontribusi terhadap literatur dengan menyediakan bukti empiris terkait hubungan antara koneksi politik dan kualitas auditor, dan manajemen laba sebagai variabel pemoderasi yang kurang tereksplorasi. Hasil penelitian ini relevan untuk regulator terkait tata kelola perusahaan, dan investor dan kreditor yang pembuatan keputusan investasi dan pembiayannya yang mendasarkan pada laporan keuangan.

\section{TINJAUAN LITERATUR DAN PERUMUSAN HIPOTESIS}

Masalah agensi dan asimetri informasi merupakan dasar mengapa manajemen menyampaikan pengungkapan dan melakukan pelaporan keuangan kepada pihak luar (Healy \& Palepu, 2001). Permasalahan agensi terjadi ketika pemilik perusahaan memberikan otoritas kepada pihak lain untuk menjalankan perusahaan, tetapi agen berkemungkinan dalam menjalankan tugasnya tidak bertindak sesuai dengan kepentingan pemilik (Jensen \& Meckling, 1976).

Permasalahan agensi dipengaruhi oleh struktur kepemilikan. Struktur kepemilikan yang terkonsentrasi merupakan karakteristik dari perusahaan yang terdaftar di pasar modal yang berkembang (Fan \& Wong, 2005). Berbeda dengan struktur kepemilikan di US yang umumnya tidak terkonsentrasi, Carney dan Child (2013) melaporkan bahwa perusahaan di Indonesia 
didominiasi oleh struktur kepemilikan yang terkonsentrasi yakni sebesar 51.1\%. Untuk alasan ini, di Indonesia, permasalahan agensi lebih dapat dijelaskan oleh masalah agensi tipe kedua yakni antara investor pengendali dan investor minoritas daripada masalah agensi tipe pertama, antara investor dan manajer.

Audit yang berkualitas dapat berperan sebagai tata kelola yang efektif untuk mengurangi masalah agensi dan asimetri informasi (Fan \& Wong, 2005). Hal ini karena audit yang berkualitas tidak hanya mampu menemukan salah saji yang material, tetapi juga melaporkan hal tersebut (Deangelo, 1981). Konsisten dengan argumen ini, penelitian sebelumnya telah melaporkan bahwa auditor yang berkualitas dapat meningkatkan transparansi akuntansi (Guedhami dkk., 2009, 2014; Liu dkk., 2016) dan kredibilitas laporan keuangan (Gul dkk., 2010).

Terdapat dua argumentasi yang memprediksi hubungan antara perusahaan yang terkoneksi politik dan kualitas auditor. Di satu sisi, perusahaan yang terkoneksi politik tidak akan memilih auditor yang berkualitas karena manajemen perusahaan tersebut mungkin melakukan ekspropriasi terhadap sumber daya perusahaan (Guedhami dkk., 2014). Lebih lanjut, transparansi akuntansi tidak diperlukan untuk mendapatkan sumber pendanaan karena perusahaan tersebut memperoleh akses pendanaan yang mudah dan biaya bunga yang rendah dari bank BUMN (Bliss \& Gul, 2012; Claessens dkk., 2008; Faccio, 2006; Wang dkk., 2008). Untuk alasan ini, perusahaan yang terkoneksi politik menikmati biaya ekuitas yang lebih rendah karena investor menganggap perusahaan ini memiliki keunggulan kompetitif (Boubakri dkk., 2012).

Di sisi lain, perusahaan yang terkoneksi politik akan memilih auditor yang berkualitas. Auditor yang berkualitas mampu mereduksi informasi asimetris dan memberikan sinyal positif kepada partisipan pasar bahwa perusahaan telah dikelola dengan baik (Cheng dkk., 2015; Guedhami dkk., 2014; Habib dkk., 2017b; Knechel dkk., 2008) karena partisipan pasar umumnya menilai perusahaan yang terkoneksi politik lebih berisiko (Bliss \& Gul, 2012).

\section{Koneksi Politik dan Kualitas Audit}

Dalam rangka meminimalkan masalah agensi, perusahaan yang terkoneksi politik akan memilih auditor yang berkualitas sehingga mampu mereduksi informasi asimetris dan memberikan sinyal positif kepada partisipan pasar bahwa perusahaan telah dikelola dengan baik (Cheng dkk., 2015; Guedhami dkk., 2014; Habib dkk., 2017b; Knechel dkk., 2008). Hal ini karena auditor yang berkualitas berkemungkinan mendeteksi dan memiliki kemampuan untuk memaksa klien mereka untuk mengungkapkan informasi yang berkualitas dan rinci (Gul dkk., 2010).

Karena partisipan pasar umumnya menilai perusahaan yang terkoneksi politik lebih berisiko (Bliss \& Gul, 2012), maka perusahaan yang terkoneksi politik berusaha untuk meningkatkan kredibilitas laporan keuangan dan transparansi akuntansi dengan memilih auditor yang berkualitas. Sesuai dengan argumen ini, hasil penelitian sebelumnya telah melaporkan bahwa perusahaan terkoneksi politik akan memilih auditor yang berkualitas (Armadiyanti \& Iswati, 2019; Guedhami dkk., 2014; Harymawan \& Nowland, 2016).

\section{$\boldsymbol{H}_{\mathbf{I}}$ : Perusahaan yang terkoneksi politik lebih berkemungkinan memilih auditor yang berkualitas daripada auditor yang tidak berkualitas.}

\section{Koneksi Politik, Kualitas Audit dan Akrual Diskresioner}

Perusahaan yang terkoneksi politik mendapatkan bebagai keuntungan dari kedekatannya dengan pemerintah, seperti mendapat perlakukan istimewa dari Bank BUMN, lebih berkemungkinan untuk memenangkan tender, pajak yang lebih ringan, dan pengawasan dari badan regulator yang tidak ketat (Faccio, 2006). Karena perusahaan mendapatkan keuntungan dari kedekatannya dengan pemerintah, pemegang saham pengendali di perusahaan yang terkoneksi politik lebih berkesempatan untuk mengekpropriasi sumber daya perusahaan (Guedhami dkk., 2014), seperti melakukan tunneling melalui transaksi dengan perusahaan yang berafiliasi (Chaney dkk., 2011; Habib dkk., 2017a; He dkk., 2014; Shleifer \& Vishny, 1997) dan memberikan kompensasi yang berlebihan (Anderson \& Reeb, 2003). Salah satu cara untuk menutupi 
ekspropriasi tersebut dengan melakukan manajemen laba (Chaney dkk., 2011; Habib dkk., 2017b). Oleh karena itu, perusahaan terkoneksi politik akan menutupi ekspropriasi tersebut dengan melakukan manajemen laba sehingga perusahaan terkoneksi politik cenderung memilih auditor yang tidak berkualitas.

$\boldsymbol{H}_{\mathbf{2}}$ Perusahaan yang terkoneksi politik cenderung memilih auditor yang tidak berkualitas ketika melakukan manajemen laba.

\section{METODE PENELITIAN}

\section{Desain Riset}

Penelitian ini menggunakan pendekatan kuantitatif sehingga pengujian statistik digunakan untuk menarik kesimpulan. Sampel penelitian ini terdiri atas seluruh perusahaan nonfinansial yang terdaftar di Bursa Efek Indonesia (BEI) dari tahun 2017 hingga tahun 2018. Data keuangan diperoleh dari BvD Osiris dan profil direksi dan komisaris diperoleh dari laporan tahunan, dan informasi terkait audit diperoleh dari IDX Fact Book.

Sampel awal diperoleh sejumlah 1350 perusahaan-tahun. Setelah itu, peneliti menerapkan kriteria penyampelan yaitu dengan menghapus perusahaan yang memiliki ekuitas negatif (Bliss dkk., 2011) sejumlah 74 perusahaan-tahun, menghapus perusahaan finansial sejumlah 166 perusahaan-tahun, dan menghapus perusahaan dengan data yang tidak lengkap sejumlah 215 perusahaan-tahun. Dengan demikian, sampel akhir sejumlah 895 perusahaan-tahun.

Perusahaan dikategorikan memiliki koneksi politik jika salah satu dari dewan direksi atau komisaris adalah anggota parlemen, kepala pemerintahan atau menteri, atau eksekutif pemerintah tingkat atas lainnya (Tihanyi dkk., 2019). Pengukuran untuk perusahaan terkoneksi politik menggunakan variabel dummy, nilai 1 jika perusahaan terkoneksi politik, dan nilai 0 jika tidak.

Pengukuran kualitas audit menggunakan variabel dummy, nilai 1 untuk KAP yang berafilasi dengan big-four dan nilai 0 jika tidak (Guedhami dkk., 2014). Lebih lanjut, manajemen laba dalam penelitian ini diestimasi menggunakan akrual diskresioner dengan model Jones modifikasian.

$\mathrm{AK}_{\mathrm{i} / \mathrm{A}} / \mathrm{A}_{\mathrm{it}-1}=\beta_{0}\left(1 / \mathrm{A}_{\mathrm{it}-1}\right)+\beta_{1}\left(\Delta \mathrm{PEN}_{\mathrm{i} /} / \mathrm{A}_{\mathrm{it}-1}\right)+\beta_{2}\left(\mathrm{AT}_{\mathrm{i} / \mathrm{A}} / \mathrm{A}_{\mathrm{it}-1}\right)+\varepsilon_{\mathrm{it}}$

AK adalah akrual yang diperoleh dari laba bersih setelah pajak dikurangi aliran kas operasi. Lebih lanjut, $t$ dan $i$ masing-masing merepresentasikan tahun dan perusahaan. A merupakan aset pada tahun sebelumnya (t-1). $\triangle$ PEN yakni perubahan pendapatan. AT adalah aset tetap. $\beta_{0}, \beta_{1}$, dan $\beta_{2}$ adalah intersep dan slop koefisien yang diestimasi.

Setelah melakukan regresi pada persamaan pertama untuk mendapatkan total akrual dan parameter spesifik yang diestimasi, penelitian ini melakukan perhitungan di persamaan kedua untuk mendapatkan akrual nondiskresioner:

$\mathrm{NAC}=\beta_{0}\left(1 / \mathrm{TA}_{\mathrm{i}-1}\right)+\beta_{1}\left(\Delta \mathrm{PEN}_{\mathrm{i}-}-\Delta \mathrm{PIU}_{\mathrm{i} /} / \mathrm{TA}_{\mathrm{i}-1}\right)+\beta_{2}\left(\mathrm{AT}_{\mathrm{i} /} / \mathrm{TA}_{\mathrm{i}-1}\right)$

$\triangle$ PIUadalah perubahan piutang. AND merupakan akrual non-diskresioner. Lebih lanjut, total akrual dikurangi dengan akrual nondiskresioner untuk mendapatkan akrual diskresioner (AD) seperti di persamaan ketiga:

$\mathrm{AD}=\mathrm{AK}-\mathrm{NAC}$

\section{Pengujian Hipotesis Pertama}

Hipotesis pertama diuji menggunakan analisis regresi logistik. Hipotesis pertama dalam penelitian ini tentang perusahaan yang terkoneksi politik akan memilih auditor yang berkualitas atau tidak. Model regresi sebagai berikut: 
$\mathrm{AUD}=\beta_{0}+\beta_{1} \mathrm{POLCON}+\beta_{2} \mathrm{AD}+\beta_{3} \mathrm{LEV}+\beta_{4} \mathrm{ROA}+\beta_{5} \mathrm{LNSIZE}+\beta_{6} \mathrm{GROWTH}+\varepsilon$

AUD merupakan kualitas audit yang diukur menggunakan variabel dummy, nilai 1 untuk KAP yang berafilasi dengan big-four dan nilai 0 jika tidak (Guedhami dkk., 2014). POLCON adalah perusahaan yang terkoneksi politik yang diukur menggunakan variabel dummy, nilai 1 jika perusahaan terkoneksi politik, dan nilai 0 jika tidak.

Variabel independen lain di persamaan 4 merupakan variabel kontrol. GROWTH yaitu pertumbuhan perusahaan yang diproksi penjualan akhir tahun minus penjualan awal tahun dibagi dengan penjualan awal tahun (Rakhman, 2018). LEV (leverage) diukur menggunakan total utang dibagi total aset. ROA (return on asset) diukur menggunakan laba bersih setelah pajak dibagi dengan total aset. LNSIZE yaitu ukuran perusahaan yang diproksi menggunakan total aset perusahaan yang dilogaritmanaturalkan (Hazarika dkk., 2012)

\section{Pengujian Hipotesis Kedua}

Penelitian ini menggunakan regresi logistik dengan interaksi untuk menguji hipotesis kedua. Model persamaannya sebagai berikut:

$\mathrm{AUD}=\beta_{0}+\beta_{1} \mathrm{POLCON}+\beta_{2} \mathrm{AD}+\beta_{3}$ POLCON ${ }^{*} \mathrm{AD}+\beta_{4} \mathrm{ROA}+\beta_{3}$ GROWTH $+\beta_{6} \mathrm{LNSIZE}+\beta_{3} \mathrm{LEV}+\varepsilon$

AUD merupakan auditor yang memiliki nilai 1 untuk perusahaan yang diaudit oleh salah satu KAP empat besar dan 0 jika tidak. POLCON ${ }^{*}$ AD merupakan variabel interaksi antara variabel perusahaan terkoneksi politik (POLCON) dengan variabel akrual diskresioner (AD). Lebih lanjut, variabel independen lain di persamaan 5 merupakan variabel kontrol.

\section{HASIL DAN PEMBAHASAN}

Tabel 2 di Panel A melaporkan statistik deskriptif untuk keseluruhan variabel. Konsisten dengan penelitian Harymawan (2020), penelitian ini melakukan winsorizing pada tingkat 1 dan 99 persen untuk seluruh variabel kontinu dalam rangka untuk meminimalkan data ekstrem. Sebagai variabel dependen, auditor (AUD) menampilkan bahwa auditor non-big four mengaudit lebih banyak perusahaan-perusahaan daripada auditor big-four, masing-masing sebesar 793 atau 88,6 persen dan sejumlah 102 atau 11.4 persen dari observasi. Hal ini tidak mengejutkan karena kuantitas auditor non-big four lebih banyak secara substansial daripada jumlah auditor big-four. Lebih lanjut, sebagai variabel independen utama, koneksi politik (POLCON) sejumlah 298 observasi atau sekitar sepertiga lebih sedikit daripada perusahaan yang tidak terkoneksi politik sebanyak 597 atau $66.70 \%$. Di sisi lain, akrual diskresioner (AD), sebagai variabel pemoderasi, memiliki nilai rerata sebesar 0.003 yang mengindikasikan bahwa rata-rata perusahaan cenderung melakukan manajemen laba yang meningkatkan laba.

Seperti yang terlihat pada Tabel 2 di Panel B, secara rata-rata, perusahaan yang terkoneksi politik (POLCON) lebih banyak diaudit oleh auditor big-four sebesar 0.191 daripada perusahaan yang tidak terkoneksi politik sejumlah 0.075 dan perbedaan ini signifikan pada tingkat 1 persen. Hal ini sebagai bukti awal bahwa perusahaan yang tekoneksi politik cenderung memilih auditor yang berkualitas. Selain itu, rata-rata akrual diskresioner (DA) yang diaudit oleh auditor big four lebih kecil sebesar -0.010 jika dibanding dengan rata-rata akrual diskresioner yang diaudit oleh auditor nonbig four sebesar 0.010 dan perbedaan ini, secara statistik, signifikan pada tingkat 1 persen. Hal ini mengindikasikan bahwa auditor yang berkualitas lebih mampu mereduksi manajemen laba. 
Tabel 2 Statistik Deskriptif dan Uji Univariat

\begin{tabular}{|c|c|c|c|c|c|c|c|c|}
\hline \multicolumn{6}{|c|}{ Panel A: Statistik Deskriptif } & \multicolumn{3}{|c|}{ Panel B: Uji Univariat } \\
\hline Variabel Kontinu & Obs. & Rerata & Dev. Std. & Min. & Max. & $\begin{array}{l}\text { Mean } \\
\text { Non- } \\
\text { AUD } \\
\end{array}$ & $\begin{array}{l}\text { Mean } \\
\text { AUD }\end{array}$ & t-stat. \\
\hline $\mathrm{AD}$ & 895 & 0,003 & 0,113 & $-0,436$ & 0,416 & 0,010 & $-0,010$ & $\begin{array}{l}2,71 \\
9^{* * *} \\
- \\
5,11\end{array}$ \\
\hline ROA & 895 & 0,034 & 0,078 & $-0,199$ & 0,370 & 0,024 & 0,054 & $\begin{array}{l}6^{* * *} \\
2,54\end{array}$ \\
\hline GROWTH & 895 & 0,325 & 1,682 & $-0,721$ & 20,630 & 0,398 & 0,178 & $\begin{array}{l}6^{* *} \\
1,43\end{array}$ \\
\hline LNSIZE & 895 & 20,071 & 3,567 & 11,134 & 25,293 & 20,210 & 19,792 & \\
\hline $\begin{array}{l}\text { LEV } \\
\text { Variabel } \\
\text { diskrit } \\
\end{array}$ & 895 & 0,461 & $\begin{array}{l}0,211 \\
0 \\
\end{array}$ & 0,027 & $\begin{array}{r}0,935 \\
1 \\
\end{array}$ & 0,456 & 0,471 & 0 \\
\hline $\begin{array}{l}\text { POLCON } \\
\text { AUD }\end{array}$ & $\begin{array}{l}895 \\
895 \\
\end{array}$ & $\begin{array}{l}597 \\
793\end{array}$ & $\begin{array}{l}(66,70 \%) \\
(88,60 \%)\end{array}$ & $\begin{array}{l}298 \\
102\end{array}$ & $\begin{array}{l}(33,30 \%) \\
(11,40 \%) \\
\end{array}$ & 0,075 & 0,191 & $\begin{array}{l}4,58 \\
9^{* * *}\end{array}$ \\
\hline
\end{tabular}

Tanda * $,{ }^{* *},{ }^{* *}$ mengindikasikan masing-masing 10\%, 5\%, dan 1\%, two-tail test.

Tabel 3 Pearson Correlation

\begin{tabular}{|c|c|c|c|c|c|c|c|}
\hline & 1 & 2 & 3 & 4 & 5 & 6 & 7 \\
\hline 1. AUD & 1 & & & & & & \\
\hline 2. POLCON & $0,172 * *$ & 1 & & & & & \\
\hline 3. AD & $-\left(0,082^{* *}\right.$ & 0,012 & 1 & & & & \\
\hline 4. $\mathrm{ROA}$ & $0,183^{* * *}$ & $0,124^{* * *}$ & $0,286^{* * *}$ & 1 & & & \\
\hline 5. GROWTH & $-0,062^{*}$ & $-0,023$ & 0,027 & $-0,008$ & 1 & & \\
\hline 6. SIZE & $-0,055^{*}$ & 0,034 & 0,005 & $0,067 * *$ & $-0,016$ & 1 & \\
\hline 7. LEV & 0,032 & 0,001 & $-0,153^{* * *}$ & $-0,257$ * * * & $-0,023$ & $-0,034$ & 1 \\
\hline
\end{tabular}

Tabel 3 menyediakan informasi terkait korelasi di antara variabel. Perusahaan yang terkoneksi politik (POLCON) berkorelasi positif dengan auditor (AUD) dengan tingkat signifikansi 5 persen. Korelasi ini mengindikasikan bahwa perusahaan yang terkoneksi politik cenderung memilih auditor yang berkualitas. Di sisi lain, akrual diskresioner (AD) berkorelasi negatif dengan auditor (AUD) dengan tingkat signifikansi 5 persen. Hal ini menunjukkan bahwa auditor yang berkualitas mampu memitigasi praktik manajemen laba.

Tabel 4 Hasil Regresi Logistik

\begin{tabular}{lcccrrr}
\hline & \multicolumn{2}{c}{ Panel A } & \multicolumn{2}{c}{ Panel B } & \multicolumn{2}{c}{ Panel C } \\
Variabel & \multicolumn{2}{c}{ Dependen= AUD } & \multicolumn{2}{c}{ Dependen= AUD } & \multicolumn{2}{c}{ Dependen= AUD } \\
\hline & Koefisien & Z-stat. & Koefisien & Z-stat, & Koefisien & Z-stat, \\
POLCON & 0,966 & $4,38^{* * *}$ & 0,972 & $4,38^{* * *}$ & 1,013 & $4,45^{* * *}$ \\
AD & & & $-2,807$ & $-3,92^{* * *}$ & $-2,493$ & $-3,41^{* * *}$ \\
POLCON_AD & & & & & $-5,238$ & $-1,82^{*}$ \\
ROA & 5,673 & $5,34^{* * *}$ & 6,819 & $6,08^{* * *}$ & 6,993 & $6,2^{* * *}$ \\
GROWTH & $-0,204$ & $-1,70^{*}$ & $-0,205$ & $-1,64$ & $-0,206$ & $-1,66^{*}$ \\
LNSIZE & $-0,044$ & $-2,20^{* *}$ & $-0,047$ & $-2,30^{* *}$ & $-0,048$ & $-2,37^{* *}$ \\
LEV & 0,898 & $2,41^{* * *}$ & 0,795 & $2,11^{* *}$ & 0,853 & $2,25^{* *}$ \\
Constant & $-0,510$ & $-1,12$ & $-0,460$ & $-1,01$ & $-0,457$ & $-1,00$ \\
Psd. R-Square & 0.0573 & & 0.0715 & & 0.0745 & \\
Observations & 895 & & 895 & & 895 & \\
\hline
\end{tabular}

Tanda ${ }^{* * *},{ }^{* *}$ mengindikasikan masing-masing 10\%, 5\%, dan 1\%, two-tail test. 
Tabel 4 pada Panel A menyediakan hasil regresi logistik untuk pengujian hipotesis pertama. Seperti yang diekspektasikan, variabel koneksi politik (POLCON) berpengaruh positif terhadap variabel auditor dengan koefisien sebesar 0.972 yang signifikan pada tingkat 5 persen. Hasil ini mendukung hipotesis pertama yang menyatakan bahwa perusahaan yang terkoneksi politik lebih berkemungkinan memilih auditor yang berkualitas daripada auditor yang tidak berkualitas. Lebih lanjut, hasil ini sesuai dengan teori agensi, yang memprediksi adanya informasi asimetris sehingga perusahaan terkoneksi politik memilih auditor yang berkualitas untuk meminimalkan asimetri tersebut dan memberikan sinyal positif kepada partisipan pasar bahwa perusahaan telah dikelola dengan baik (Cheng dkk., 2015; Guedhami dkk., 2014; Habib dkk., 2017b; Knechel dkk., 2008). Lebih lanjut, hasil penelitian ini sesuai dengan hasil penelitian sebelumnya (Armadiyanti \& Iswati, 2019; Guedhami dkk., 2014; Harymawan \& Nowland, 2016).

Pada Panel B, seperti yang diekspektasikan, variabel akrual diskresioner (AD) memiliki koefisien negatif sebesar -2.807 dan signifikan dengan tingkat 1 persen. Hasil ini menyediakan bukti bahwa akrual diskresioner di perusahaan yang diaudit oleh auditor yang berkualitas lebih rendah daripada akrual diskresioner di perusahaan yang tidak diaudit oleh auditor yang berkualitas. Hal ini karena auditor yang berafiliasi dengan KAP big-four lebih memiliki sumberdaya manusia dan finansial yang lebih memadai untuk melakukan audit yang lebih berkualitas. Hasil penelitian ini mendukung hasil penelitian sebelumnya dari Cheng dkk. (2015) yang menemukan bahwa auditor yang berkualitas memiliki hubungan negatif dengan akrual diskresioner.

Panel C menyediakan hasil Moderated Regression Analysis (MRA) dengan mengikutsertakan akrual diskresioner sebagai variabel pemoderasi untuk pengujian hipotesis kedua. Variabel interakasi antara koneksi politik dan akrual diskresioner (POLCON_AD) memiliki koefisien negatif sebesar -5.238 dan signifikan pada tingkat 5 persen. Hasil ini mendukung hipotesis kedua yang menyatakan bahwa perusahaan yang terkoneksi politik cenderung memilih auditor non-big four ketika melakukan manajemen laba. Lebih lanjut, hasil penelitian ini sejalan dengan moral hazard, tindakan salah satu pihak (pemegang saham pengendali) yang tidak dapat diobservasi oleh pihak lainnya (pemegang saham minoritas) yang diperburuk dengan pemilihan auditor yang kurang berkualitas. Hal ini dimaksudkan untuk memaksimalkan utilitas pemegang saham pengendali. Perusahaan terkoneksi politik memiliki banyak keuntungan dari hubungannya dengan politisi atau birokrat (Faccio, 2006) sehingga pemegang saham pengendali di perusahaan yang terkoneksi politik lebih berkesempatan untuk mengekpropriasi sumber daya perusahaan (Guedhami dkk., 2014). Ekspropriasi tersebut ditutupi dengan melakukan manajemen laba (Chaney dkk., 2011; Habib dkk., 2017b) sehingga perusahaan terkoneksi politik tidak akan memilih auditor yang berkualitas.

\section{KETERBATASAN PENELITIAN}

Meskipun melaporkan bahwa perusahaan yang terkoneksi politik tidak menggunakan auditor yang berkualitas ketika menggunakan manajemen laba, penelitian ini tidak dapat menyediakan bukti secara langsung untuk mendukung dugaan ini. Oleh karena itu, penelitian selanjutnya dapat mengembangkan dengan melakukan survei kepada perusahaan yang terkoneksi politik untuk mendapatkan hasil yang lebih komprehensif. Selain itu, penelitian ini melakukan observasi perusahaan nonfinansial selama dua tahun karena kesulitan untuk mengumpulkan data terkait variabel koneksi politik di laporan tahunan. Dengan demikian, penelitian selanjutnya dapat memperluas periode penelitian.

\section{KESIMPULAN}

Dengan menggunakan sampel sejumlah 895 observasi di perusahaan nonfinansial yang terdaftar di Bursa Efek Indonesia, penelitian ini menginvestigasi hubungan antara perusahaan yang terkoneksi politik dan kualitas auditor dan apakah hubungan ini dimoderasi oleh manajemen laba. Hasil penelitian ini menyediakan bukti empiris terkait terdapat hubungan positif antara koneksi 
politik dan kualitas audit. Hal ini mengindikasikan bahwa perusahaan yang terkoneksi politik memberikan sinyal positif kepada partisipan pasar bahwa perusahaan telah dikelola dengan lebih akuntabel dan transparan dalam rangka untuk merevisi persepsinya yang menganggap perusahaan yang terkoneksi politik cenderung lebih berisiko. Selain itu, hasil penelitian ini melaporkan manajemen laba memoderasi hubungan koneksi politik dan kualitas auditor. Hasil ini mengungkapkan bahwa ketika melakukan manajemen laba, perusahaan yang terkoneksi politik memilih auditor tidak berkualitas dalam rangka untuk menutupi praktik manajemen labanya tersebut.

Penelitian ini berkontribusi terhadap literatur dengan menyediakan bukti empiris terkait hubungan antara koneksi politik dan kualitas auditor, dan manajemen laba sebagai variabel pemoderasi yang kurang tereksplorasi. Hasil penelitian ini relevan untuk regulator terkait tata kelola perusahaan, dan investor dan kreditor yang pembuatan keputusan investasi dan pembiayannya yang mendasarkan pada laporan keuangan.

\section{DAFTAR PUSTAKA}

Anderson, R. C., \& Reeb, D. M. (2003). Founding-family ownership and firm performance: evidence from the S\&P 500. The Journal of Finance, 58(3), 1301-1328. https://doi.org/10.1111/1540-6261.00567

Armadiyanti, P., \& Iswati, S. (2019). Corporate political connection and audit quality. Jurnal Akuntansi dan Keuangan Indonesia, 16(2), 122-140. https://doi.org/10.21002/jaki.2019.07

Bliss, M. A., \& Gul, F. A. (2012). Political connection and leverage: Some Malaysian evidence. Journal of Banking \& Finance, 36(8), 2344-2350. https://doi.org/10.1016/j.jbankfin.2012.04.012

Bliss, M. A., Gul, F. A., \& Majid, A. (2011). Do political connections affect the role of independent audit committees and CEO Duality? Some evidence from Malaysian audit pricing. Journal of $\begin{array}{llll}\text { Contemporary Accounting \& } \quad \text { Economics, } & 7(2), & 82-98 .\end{array}$ https://doi.org/10.1016/j.jcae.2011.10.002

Boubakri, N., Guedhami, O., Mishra, D., \& Saffar, W. (2012). Political connections and the cost of equity capital. Journal of Corporate Finance, 18(3), 541-559. https://doi.org/10.1016/j.jcorpfin.2012.02.005

Carney, R. W., \& Child, T. B. (2013). Changes to the ownership and control of East Asian corporations between 1996 and 2008: The primacy of politics. Journal of Financial Economics, 107(2), 494-513. https://doi.org/10.1016/j.jfineco.2012.08.013

Chaney, P. K., Faccio, M., \& Parsley, D. (2011). The quality of accounting information in politically connected firms. Journal of Accounting and Economics, 51(1-2), 58-76. https://doi.org/10.1016/j.jacceco.2010.07.003

Cheng, C.-L., Hsu, C.-S., \& Kung, F.-H. (2015). Political connections, managerial incentives and auditor choice: evidence from China. Pacific Accounting Review, 27(4), 441-465. https://doi.org/10.1108/par-10-2013-0096

Claessens, S., Feijen, E., \& Laeven, L. (2008). Political connections and preferential access to finance: The role of campaign contributions. Journal of Financial Economics, 88(3), 554-580. https://doi.org/10.1016/i.jineco.2006.11.003

DeAngelo, L. E. (1981). Auditor size and audit quality. Journal of Accounting and Economics, 3(3), 183-199. https://doi.org/10.1016/0165-4101(81)90002-1

Faccio, M. (2006). Politically Connected Firms. The American Economic Review, 96(1), 369-386. https://doi.org/10.2139/ssrn.444960

Fan, J. P. H., \& Wong, T. J. (2005). Do External Auditors Perform a Corporate Governance Role in Emerging Markets? Evidence from East Asia. Journal of Accounting Research, 43(1), 3572. https://doi.org/10.1111/j.1475-679x.2004.00162.x 
Francis, J., LaFond, R., Per M. Olsson, \& Schipper, K. (2004). Costs of Equity and Earnings Attributes. The Accounting Review, 79(4), 967-1010. Diakses dari http://www.jstor.org/stable/4093083

Guedhami, O., \& Pittman, J. A. (2006). Ownership Concentration in Privatized Firms: The Role of Disclosure Standards, Auditor Choice, and Auditing Infrastructure. Journal of Accounting Research, 44(5), 889-929. https://doi.org/10.1111/j.1475-679x.2006.00219.x

Guedhami, O., Pittman, J. A., \& Saffar, W. (2009). Auditor choice in privatized firms: Empirical evidence on the role of state and foreign owners. Journal of Accounting and Economics, 48(23), 151-171. https://doi.org/10.1016/j.jacceco.2009.08.003

Guedhami, O., Pittman, J. A., \& Saffar, W. (2013). Auditor Choice in Politically Connected Firms. Journal of Accounting Research, 52(1), 107-162. https://doi.org/10.1111/1475-679x.12032

Gul, F. A., Kim, J.-B., \& Qiu, A. A. (2010). Ownership concentration, foreign shareholding, audit quality, and stock price synchronicity: Evidence from China. Journal of Financial Economics, 95(3), 425-442. https://doi.org/10.1016/j.jfineco.2009.11.005

Habib, A., Muhammadi, A. H., \& Jiang, H. (2017a). Political connections, related party transactions, and auditor choice: Evidence from Indonesia. Journal of Contemporary Accounting and Economics, 13(1), 1-19. https://doi.org/10.1016/j.jcae.2017.01.004

Habib, A., Muhammadi, A. H., \& Jiang, H. (2017b). Political Connections and Related Party Transactions: Evidence from Indonesia. International Journal of Accounting, 52(1), 45-63. https://doi.org/10.1016/j.intacc.2017.01.004

Harymawan, I. (2020). Military reform, militarily-connected firms and auditor choice. Managerial Auditing Journal, 35(6), 705-729. https://doi.org/10.1108/maj-04-2019-2258

Harymawan, I., \& Nowland, J. (2016). Political connections and earnings quality. International Journal of Accounting \& Information Management, 24(4), 339-356. https://doi.org/10.1108/ijaim-05-2016-0056

Hazarika, S., Karpoff, J. M., \& Nahata, R. (2012). Internal corporate governance, CEO turnover, and earnings management. Journal of Financial Economics, 104(1), 44-69. https://doi.org/10.1016/j.jfineco.2011.10.011

He, X., Rui, O., Zheng, L., \& Zhu, H. (2014). Foreign ownership and auditor choice. Journal of $\begin{array}{llll}\text { Accounting } & \text { Public }\end{array}$ https://doi.org/10.1016/j.jaccpubpol.2014.04.002

Healy, P. M., \& Palepu, K. G. (2001). Information asymmetry, corporate disclosure, and the capital markets: A review of the empirical disclosure literature. Journal of Accounting and Economics, 31(1-3), 405-440. https://doi.org/10.1016/s0165-4101(01)00018-0

Jensen, M. C., \& Meckling, W. H. (1976). Theory of the firm: Managerial behavior, agency costs and ownership structure. Journal of Financial Economics, 3(4), 305-360. https://doi.org/10.1016/0304-405x(76)90026-x

Knechel, W. R., Niemi, L., \& Sundgren, S. (2008). Determinants of Auditor Choice: Evidence from a Small Client Market. International Journal of Auditing, 12(1), 65-88. https://doi.org/10.1111/j.1099-1123.2008.00370.x

Liu, Y., Li, X., Zeng, H., \& An, Y. (2016). Political connections, auditor choice and corporate accounting transparency: evidence from private sector firms in China. Accounting \& Finance, 57(4), 1071-1099. https://doi.org/10.1111/acfi.12207

Rakhman, F. (2018). Can partially privatized SOEs outperform fully private firms? Evidence from Indonesia. Research in International Business and Finance, 45, 285-292. https://doi.org/10.1016/j.ribaf.2017.07.160

Shleifer, A., \& Vishny, R. W. (1997). A Survey of Corporate Governance. The Journal of Finance, 52(2), 737-783. https://doi.org/10.1111/j.1540-6261.1997.tb04820.x

Tihanyi, L., Aguilera, R. V., Heugens, P., van Essen, M., Sauerwald, S., Duran, P., \& Turturea, R. (2019). State Ownership and Political Connections. Journal of Management, 45(6), 22932321. https://doi.org/10.1177/0149206318822113 
Vernando; Ainy / Reviu Akuntansi dan Bisnis Indonesia, 5(2), 112-121.

Wang, Q., Wong, T. J., \& Xia, L. (2008). State ownership, the institutional environment, and auditor choice: Evidence from China. Journal of Accounting and Economics, 46(1), 112-134. https://doi.org/10.1016/j.jacceco.2008.04.001 